\title{
Utilization of winery wastes for Trichoderma viride biocontrol agent production by solid state fermentation
}

\author{
BAI Zhihui ${ }^{1,2}$, JIN Bo $^{1,3, *}$, LI Yuejie ${ }^{4}$, CHEN Jian ${ }^{2}$, LI Zuming ${ }^{5}$ \\ 1. School of Earth and Environmental Science, University of Adelaide, Adelaide, SA 5005, Australia. E-mail: zhbai@ rcees.ac.cn \\ 2. Research Centre for Eco-Environmental Sciences, Chinese Academy of Sciences, Beijing 100085, China \\ 3. Wastewater Research Unit, South Australian Water Cooperation, Bolivar, SA 5110, Australia \\ 4. Environmental Protection Bureau of Shijiazhuang City, Shijiazhuang 050021, China \\ 5. Teacher's College of Beijing Union University, Beijing 100011, China
}

Received 24 June 2007; revised 9 July 2007; accepted 30 July 2007

\begin{abstract}
Biocontrol agents are safe and environmental friendly alternatives for pesticides in agriculture application. Trichoderma viride WEBL0703 performed a high level of antagonistic activity toward a broad spectrum of phytopathogens and was determined as a biocontrol agent, which was produced by solid state fermentation using grape marc and wine lees. The maximum yield of $T$. viride conidia was up to $6.65 \times 10^{9} \mathrm{CFU} / \mathrm{g}$ initial dry substrate (IDS) after $10 \mathrm{~d}$ fermentation. As important enzymes for protecting plants from disease, chitinase, $\beta$-glucanase, and pectinase yields were $47.8 \mathrm{U} / \mathrm{g}$ IDS, $8.32 \mathrm{U} / \mathrm{g}$ IDS and $9.83 \mathrm{U} / \mathrm{g}$ IDS, respectively. These results show that it is feasible to convert winery wastes to a value-added and environmental friendly biocontrol agent.
\end{abstract}

Key words: grape marc; wine lees; biocontrol agent; Trichoderma viride; solid state fermentation

\section{Introduction}

Increasing concern for health and environmental hazards associated with the use of agrochemicals, in particular chemical pesticides, has resulted in a need for sustainability in agriculture (Thomas et al., 2003). Biocontrol agents (BCAs) have been developed as potential alternatives to agrochemicals or as part of integrated crop management systems to reduce the input of chemical pesticides and residues on postharvest fruits (Costa et al., 2001). Trichoderma strains are the most promising BCAs being able to control a wide range of plant pathogens (Guo et al., 2002). These strains used as antagonists in control of other microorganisms have been suggested to inhibit growth by several mechanisms, such as competition for nutrients, antibiosis, and production of fungal cell wall degrading enzymes (Limón et al., 2004).

However, production of Trichoderma BCAs is less prevalent till now. One of the main limitations for commercial application is the high-cost of using raw materials, such as sucrose nitrate, molasses-corn steep liquor and glucose tartrate. At this crux, a cheap raw material which comprises essential nutrients for growth of Trichoderma strains is necessary (Verma et al., 2005).

Grape marc is a waste material from pressing grapes in the winemaking process and accounts for approximately $10 \%-20 \%$ of the weight of the annual crush each vintage.

\footnotetext{
* Corresponding author. E-mail: bo.jin@ adelaide.edu.au.
}

Up to $2 \times 10^{5} \mathrm{t}$ of marc is estimated to be generated throughout Australia each year. Wine lees are also the waste from wine fermentation and represent $2 \%-6 \%$ of the total volume of wine produced. The lees contain a high concentration of organic substances, such as organic acid, yeast, protein, mucilage, and so on. If these wastes are not treated effectively they can cause a number of environmental hazards, such as surface and ground water pollution, foul odours, and so on. On the other hand, these winery wastes are good nutrients for microbial growth, and also could be used as raw materials for Trichoderma BCAs production.

Trichoderma viride is not only one of the most widely used strains against plant diseases (Markovich and Kononova, 2003), but also can improve plant growth and crop yields (Kolombet et al., 2001). This strain can produce a series of extracellular enzymes which are important factors for inhibiting plant pathogens, such as chitinase and $\beta$-glucanase which can hydrolyze plant pathogen cell wall (Markovich and Kononova, 2003), and pectinase which can elicit plant disease resistance (Bai et al., 2004). However, the results from most previous investigations for fungal BCA production were only given by numbers of the fungal spores produced (Vrije et al., 2001; Chen et $a l ., 2005)$, and few studies focused on the production of extracellular enzymes in the solid state fermentation.

The aim of this paper was to optimize the fermentation conditions for production of $T$. viride biocontrol agent 
(BCA) using winery wastes as substrates in a solid state fermentation. Biological activities as BCA were evaluated by number of fungal spores and activities of the chitinase, $\beta$-glucanase and pectinase produced by $T$. viride.

\section{Materials and methods}

\subsection{Winery wastes}

Grape marc and wine lees were obtained from Orlando Wyndham Group Pty. Ltd., Australia. Grape marc included fermented marc from red wine production and non-fermented marc from white wine production. The grape marc and wine lees were pretreated by removal of grape seeds and ethanol respectively. Grape seeds were removed from the marc by sieves and collected for food oil or functional food production. The marc was dried at $70^{\circ} \mathrm{C}$ and stored at room temperature. Ethanol was removed from the lees by distillation and collected for fuel production. Water was added to the ethanol removed lees up to the initial volume. The lees were stored at $4^{\circ} \mathrm{C}$. The pretreated marc and the lees were used as fermentation substrates throughout the investigation.

\subsection{Microorganism}

Trichoderma viride WEBL0703 used for this study was isolated from soil by our laboratory and was found to be active against a broad spectrum of phytopathogens. It was routinely maintained on Potato Dextrose Agar (PDA) slants at $4^{\circ} \mathrm{C}$ by regular sub-cultivation (no longer than 6 months).

\subsection{In vitro antagonist assays}

The antagonistic activity of $T$. viride WEBL0703 was evaluated by the method of confronting cultures (Kolombet et al., 2001), modified as follows: a point of phytopathogens with a point of $T$. viride were inoculated onto PDA plates, where it is $1 \mathrm{~cm}$ distance from the center of the Petri dish symmetrically, then incubated at $26^{\circ} \mathrm{C}$ for a few days. The growth of the fungi was recorded and area occupied by each culture was determined by visual inspection. The T. viride strain was considered antagonistic to the phytopathogens if it overgrew the phytopathogens (Figs.1 and 2).

\subsection{Inoculum preparation}

The $T$. viride strain was grown on PDA plates for 5 $\mathrm{d}$ at $30^{\circ} \mathrm{C}$, and then the conidia were harvested from the surface by adding $0.05 \%(\mathrm{~W} / \mathrm{V})$ Tween 80 sterile solution and scraping with a sterile spatula. The concentration of conidia was adjusted to $2 \times 10^{7}$ spores $/ \mathrm{ml}, 10 \mathrm{ml}$ of the spore suspension obtained was inoculated to $100 \mathrm{ml}$ of the lees culture medium (lees: water $(W / V)=1: 1, \mathrm{pH} 4.5)$ in 250-ml Erlenmeyer flask. After culture at $30^{\circ} \mathrm{C}$ on a shaker (150 r/min) for $2 \mathrm{~d}$, the inoculum was used to inoculate the subsequent fermentation immediately.

\subsection{Solid state fermentation and optimization of culture conditions}

The initial solid state medium contained $(W / W)$ : dry grape marc $15 \mathrm{~g}$, wine lees $18 \mathrm{~g}$, and tap water $15 \mathrm{ml}$ in an Erlenmeyer flask. The medium was mixed thoroughly

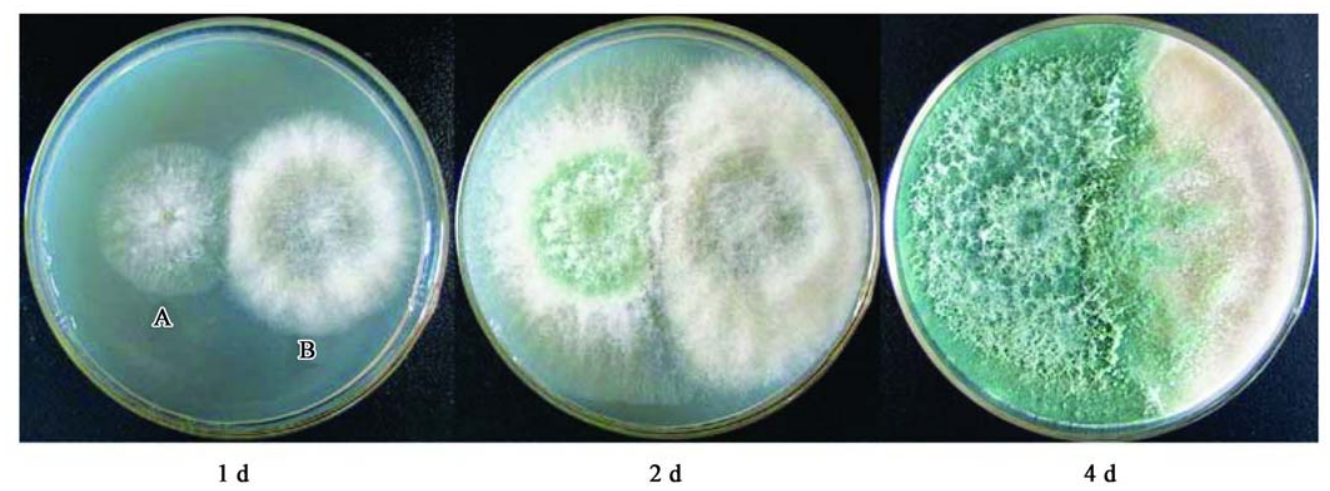

Fig. 1 Trichoderma viride overgrowing Botrytis cinerea (B. cinerea was inoculated $1 \mathrm{~d}$ earlier than T. viride). A: T. viride; B: B. cinerea.

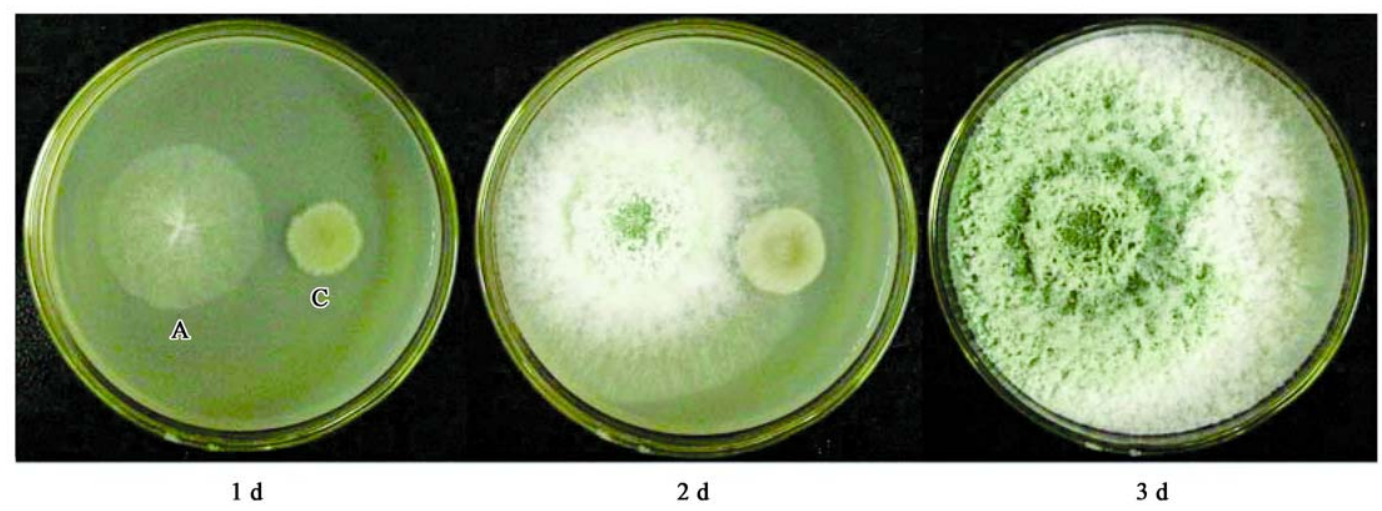

Fig. 2 Trichoderma viride overgrowing Cladosporium cucumerinum (C. cucumerinum was inoculated 1 day earlier than T. viride). A: T. viride; C: C. cucumerinum. 
and autoclaved at $121^{\circ} \mathrm{C}$ for $20 \mathrm{~min}$. After cooling to room temperature, it was inoculated with $5 \mathrm{ml}$ of inoculum and incubated at $30^{\circ} \mathrm{C}$ at $80 \%-90 \%$ relative humidity. The effects of initial moisture content in the range of $50 \%-75 \%$ $(W / W)$, wine lees content in the range of $0-50 \%(W / W)$, incubation temperature in a range of $23-35^{\circ} \mathrm{C}$ and nitrogen sources (yeast extract, peptone, wheat bran, $\left(\mathrm{NH}_{4}\right)_{2} \mathrm{SO}_{4}$ and urea) were investigated. All experiments were conducted in duplicate and the average values are reported. Key results were repeated three times to establish their validity.

\subsection{Assessment of conidia yield}

A sample of $6 \mathrm{~g}$ was mixed with $100 \mathrm{ml}$ distilled water containing $0.05 \%(W / V)$ Tween 80 in a laboratory blender for $2 \mathrm{~min}, 3$ times to separate the spores from the substrate thoroughly. Spore suspension was obtained after this step, and it was diluted to a proper density that could be suitable for counting. The spores were counted by a modified colony forming units (CFU) plating method as described by Verma et al. (2005). Spore yield was expressed as CFU/g IDS (initial dry substrate). The results were the means of duplicate determination of two independent samples, and the standard derivations were less than $10 \%$.

\subsection{Enzyme assays}

The fermented substrate was mixed thoroughly with $6 \times$ distilled water, which was based on initial dry weight of the substrate. The crude enzymes were extracted by squeezing at $60 \mathrm{~kg} / \mathrm{cm}^{2}$ in a hydraulic press and then filtering through a $0.45-\mu \mathrm{m}$ membrane filter (Whatman). The extract was used as crude enzyme for various assays.

Chitinase activity was measured according to the method described by Suresh and Chandrasekaran (1998), modified as follows: $1 \mathrm{ml}$ of appropriately diluted enzyme solution with $1 \mathrm{ml}$ of $0.5 \%$ swollen chitin in $0.1 \mathrm{~mol} / \mathrm{L}$ citrate phosphate buffer ( $\mathrm{pH} 4.0$ ) was incubated at $40^{\circ} \mathrm{C}$ for $1 \mathrm{~h}$. The reaction was terminated by placing the tubes in a boiling water bath for $5 \mathrm{~min}$, and the undigested material was removed by centrifugation at $6000 \mathrm{r} / \mathrm{min}$ for $5 \mathrm{~min}$. The reducing sugar released was measured by the 3,5dinitrosalicylic acid (DNS) method (Miller, 1959) with $\mathrm{N}$-acetyl-D-glucosamine as standard. One unit of chitinase activity was defined as the amount of enzyme that releases one micromole equivalent of GlcNAc per hour under the specified assay conditions. Enzyme yield was expressed as units/g initial dry substrate (U/g IDS).

$\beta$-Glucanase activity was analyzed by measuring the amount of glucose released from laminarin (Kulminskaya et al. 2001). One milliliter of appropriately diluted enzyme with $1.0 \mathrm{ml}$ of $0.5 \%$ laminarin solution in $0.1 \mathrm{~mol} / \mathrm{L}$ citrate phosphate buffer ( $\mathrm{pH} 4.5$ ) was incubated at $40^{\circ} \mathrm{C}$ for 20 min. The reducing sugar released was measured by the DNS method with glucose as standard. One unit of $\beta$ glucanase activity was defined as the amount required to produce one micromole of glucose per minute under the specified assay conditions. Enzyme yield was expressed as $\mathrm{U} / \mathrm{g}$ IDS.

Pectinase activity was analyzed by measuring the amount of galacturonic acid released from pectin (Bai et al. 2004). One milliliter of appropriately diluted enzyme with $1.0 \mathrm{ml}$ of $0.5 \%$ pectin solution in $0.1 \mathrm{~mol} / \mathrm{L}$ citrate phosphate buffer ( $\mathrm{pH} 4.5)$ was incubated at $40^{\circ} \mathrm{C}$ for 20 min. The reducing sugar released was measured by the DNS method with galacturonic acid as standard. One unit of pectinase activity was defined as the amount required to produce one micromole of galacturonic acid per minute under the specified assay conditions. Enzyme yield was expressed as U/g IDS.

The results of the enzyme assay were the means of duplicate determination of two independent samples. The standard derivations were less than $7 \%$.

\subsection{Other analysis}

Total sugars were measured by phenol-sulfuric acid method (Dubois et al., 1956). Glucose and fructose were determined by HPLC. A Phenomenex 00H-0138-K0 column and a refractive index deterctor were used with 4 $\mathrm{mmol} / \mathrm{L} \mathrm{H}_{2} \mathrm{SO}_{4}$ as the eluent at $50^{\circ} \mathrm{C}$. Kjeldahl nitrogen, crude fibre and ash were determined by the recommended methods of AOAC (1995). Ammonia nitrogen, total phosphorus, total solids, chemical oxygen demand (COD) and biological oxygen demand (BOD) were measured according to standard procedures described by APHA (1998). The data were calculated as average values from at least two duplicates. The standard derivations were less than 5\%, except that BOD was less than $15 \%$.

\section{Results}

\subsection{Composition of winery wastes}

Results of proximate analyses of the pretreated winery wastes are shown in Table 1. The sugar content (glucose $14.6 \%$, and fructose $15.3 \%$ ) of the non-fermented grape marc was also analyzed by HPLC (1100, Agilent, USA). Because it had a high level of carbohydrate content, the non-termented grape marc could be used as an ethanol fermentation substrate or used as animal feed. Thus, only the fermented grape marc was investigated for $T$. viride production in the following experiment. The COD and BOD in wine lees were too high to discharge into a wastewater treatment system. Therefore, the treatment or utilization of wine lees is also a key issue for the wine industry.

Table 1 Compositions of grape marc and wine lees

\begin{tabular}{llll}
\hline Composition & $\begin{array}{l}\text { Fermented } \\
\text { grape marc }\end{array}$ & $\begin{array}{l}\text { Non-fermented } \\
\text { grape marc }\end{array}$ & Wine lees \\
\hline Total carbohydrate & $2.5 \%(W / W)$ & $30.5 \%(W / W)$ & $5.6 \%(W / V)$ \\
Crude fiber & $45.7 \%(W / W)$ & $32.1 \%(W / W)$ & - \\
Ash & $7.9 \%(W / W)$ & $6.3 \%(W / W)$ & - \\
Kjeldahl nitrogen & $8.87(\mathrm{mg} / \mathrm{g})$ & $6.90(\mathrm{mg} / \mathrm{g})$ & $413(\mathrm{mg} / \mathrm{L})$ \\
Ammonia nitrogen & - & - & $31.8(\mathrm{mg} / \mathrm{L})$ \\
Total phosphorus & - & - & $48.5(\mathrm{mg} / \mathrm{L})$ \\
Total solids & - & - & $85.0(\mathrm{~g} / \mathrm{L})$ \\
COD & - & - & $102.6(\mathrm{~g} / \mathrm{L})$ \\
BOD & - & - & $70.3(\mathrm{~g} / \mathrm{L})$ \\
\hline
\end{tabular}

-: means not tested. 


\subsection{In vitro antagonist assays}

Trichoderma viride WEBL0703 performed a high level of antagonistic activity toward a broad spectrum of fungi of the genera Cladosporium, Fusarium, Fulvia, Botrytis, Aspergillus, Penicillium, Mucor and Rhizopus. The process of this evaluation was illustrated by the photos of T. viride overgrowing and inhibiting Botrytis cinerea and Cladosporium cucumerinum growth after a few days incubation (Figs.1 and 2). It can be observed clearly that pathogenic fungi could not grow towards T. viride mycelia after they overlapped on the PDA plate. However T. viride continually occupied more area on the plate, and even grew on the pathogenic fungi mycelia. Consequently, the T. viride mycelia partly covered the disease fungi mycelia. Finally, the pathogen mycelia were fully covered by $T$. viride mycelia in a few days incubation. The mycelia of Cladosporium cucumerinum, Fusarium solani, Fulvia fulva, Botrytis cinerea, Aspergillus niger, Aspergillus terreus, Penicillium oxalicum, Mucor sp. and Rhizopus sp. were fully covered by $T$. viride mycelia in 3, 4, 4, 6, 7, 3, 4, 5 and $5 \mathrm{~d}$ incubation respectively. Further investigation of T. viride against plant disease in field test is performing.

\subsection{Effect of water content on $T$. viride spores produc- tion}

The fermentation medium in each $500 \mathrm{ml}$ Erlenmeyer flask contained dry grape marc $15 \mathrm{~g}$, wine lees $18 \mathrm{~g}$ (water content $16.5 \mathrm{ml}$ ), and tap water $0,5,10,15,20,25$ and $33 \mathrm{ml}$, respectively, resulting in the water contents of the media being $50 \%, 57 \%, 62 \%, 66 \%, 69 \%, 72 \%$ and $75 \%$, respectively. Each of them was inoculated with $5 \mathrm{ml}$ of inoculum and incubated at $30^{\circ} \mathrm{C}$ for $10 \mathrm{~d}$. The effect of initial water content on $T$. viride spore production is shown in Fig.3. The highest spore yield was achieved in the range of $66 \%-72 \%$ of water content. However, the highest numbers of spores were obtained in wet substrate at $66 \%$ of water content. A higher numbers of spores in the wet substrate were convinced to be better for the postprocess of the product. Therefore, $66 \%$ of water content appeared to be optimum and was selected in the following experiment.

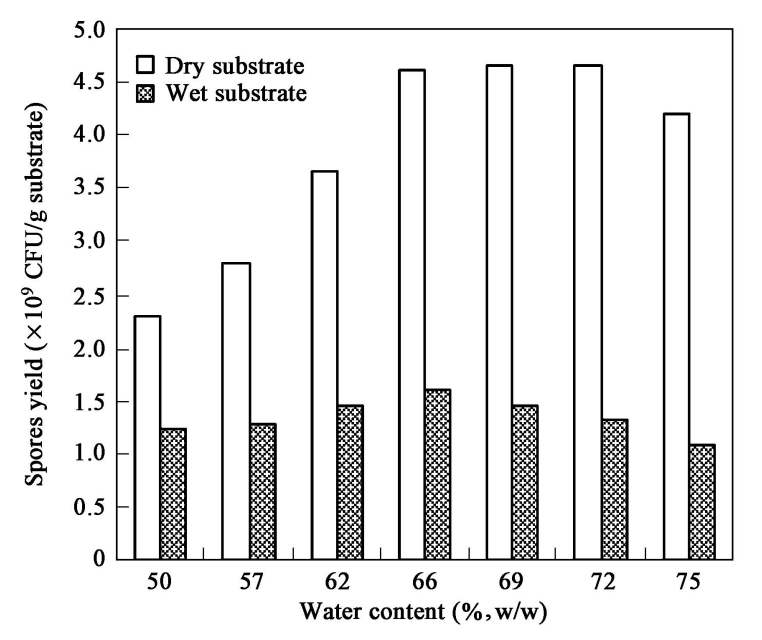

Fig. 3 Effect of water content on T. viride spore yield.

\subsection{Effect of lees content on $T$. viride spores production}

The fermentation medium and the effect of lees content of substrate on $T$. viride spore production is shown in Table 2. Due to high water content (91\%) in the lees, less water was needed to maintain a moisture level of $66 \%$ in the mediums. After inoculating with $5 \mathrm{ml}$ inoculum, the medium was incubated at $30^{\circ} \mathrm{C}$ for $10 \mathrm{~d}$. A high level of spore yield was reached in the range of $38 \%-50 \%$ of lees content. Thus, $43 \%$ of lees content was selected in the following experiment.

\subsection{Effect of culture temperature on $T$. viride spore production}

The fermentation medium contained dry grape marc 15 $\mathrm{g}$, wine lees $21 \mathrm{~g}$, and tap water $13 \mathrm{ml}$. After inoculation with $5 \mathrm{ml}$ of inoculum, the medium was incubated at 23 , $26,28,30$ and $35^{\circ} \mathrm{C}$, respectively. The time courses of $T$. viride spore production at different temperature are shown in Fig.4. The highest spore yield was given at $26^{\circ} \mathrm{C}$ after $10 \mathrm{~d}$ fermentation. Consequently, this temperature was selected in the following experiment. The spores grew very slowly after $10 \mathrm{~d}$ fermentation, it is assumed that the fermentation may be completed in $10 \mathrm{~d}$.

\subsection{Effect of nitrogen sources on $T$. viride spore and enzyme production}

The fermentation medium contained dry grape marc 15 $\mathrm{g}$, water $30 \mathrm{ml}$, and other nitrogen sources respectively.

Table 2 Effect of lees content of substrate on T. viride spores production

\begin{tabular}{lccllc}
\hline $\begin{array}{l}\text { Medium } \\
\text { No. }\end{array}$ & $\begin{array}{l}\text { Grape } \\
\text { marc }(\mathrm{g})\end{array}$ & $\begin{array}{l}\text { Water } \\
(\mathrm{ml})\end{array}$ & $\begin{array}{l}\text { Lees } \\
(\mathrm{g})\end{array}$ & $\begin{array}{l}\text { Lees content } \\
(\%, W / W)\end{array}$ & $\begin{array}{l}\text { Spore yield } \\
\left(\times 10^{9} \mathrm{CFU} / \mathrm{g} \text { IDS }\right)\end{array}$ \\
\hline 1 & 15 & 29 & 0 & 0 & 1.55 \\
2 & 15 & 24 & 6 & 13 & 2.75 \\
3 & 15 & 20 & 12 & 26 & 4.30 \\
4 & 15 & 15 & 18 & 38 & 4.78 \\
5 & 15 & 13 & 21 & 43 & 4.95 \\
6 & 15 & 10 & 25 & 50 & 4.80 \\
\hline
\end{tabular}

IDS: initial dry substrate.

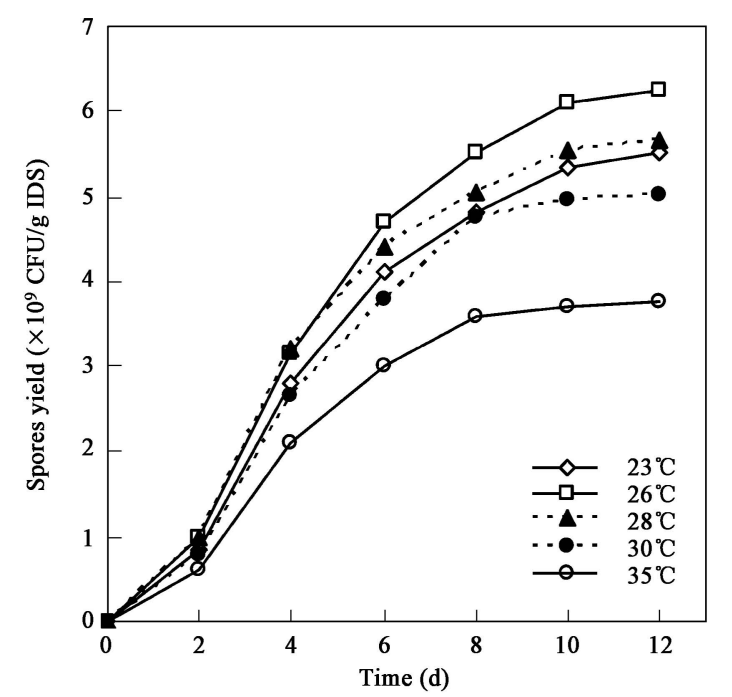

Fig. 4 Time courses of $T$. viride spores production at different temperature. IDS: initial dry substrate. 
After inoculation with $5 \mathrm{ml}$ of inoculum, the medium was incubated at $26^{\circ} \mathrm{C}$. The results of impact of nitrogen sources on the production of the spores and extracellular enzymes are presented in Table 3. It was found that $43 \%$ of lees and $1.0 \%$ peptone were the most efficient nitrogen sources for production of $T$. viride spores. Comparing with the peptone, lees are the most suitable nitrogen source due to the low cost. $1.2 \%$ of urea seemed to be the most efficient nitrogen source for production of all three extracellular enzymes. However, the spore yield appeared to be very low, because the nutrient in the fermented grape marc is limited for $T$. viride growth, whereas peptone and lees can supply a wide variety of nutrients. Higher levels of enzyme yield, as well as the highest yield of spores were achieved using $43 \%$ of lees mixed with $0.4 \%$ urea as the nitrogen source.

\section{Discussion}

Trichoderma viride used as BCA has been reported widely in the literature (Bailey et al., 1997; Zhao et al., 1998; Ejechi, 2001; Boby and Bagyaraj, 2003; Ji et al., 2005). Our current results for in vitro evaluation of the antagonistic activity of $T$. viride WEBL0703 demonstrated it was a potential candidate for BCA. For further understanding the efficiency of the BCA, in vivo investigation of the antagonistic activity is in progress. Production of the BCA with large numbers of spores or conidia and low cost are the key issues for a commercial application of the BCA (Wang et al., 2003). As a primer aim of this study, it was to optimize the fermentation conditions to achieve the highest spores yield, as well as the lowest production cost.

Solid state fermentation is a cost-effective system for utilization of agricultural waste or agro-industrial residues (Couto and Sanromán, 2006). Grape marc (even spent grape marc) is a suitable support substrate for solid state fermentation. Wine lees contain a wide variety of nutrients, including carbon source, nitrogen source and trace elements, for microbial growth. The mixture of these winery

Table 3 Effect of nitrogen sources on T. viride spores and enzymes production

\begin{tabular}{lclll}
\hline Nitrogen sources & $\begin{array}{l}\text { Spores } \\
\text { yield }\left(\times 10^{9}\right. \\
\text { CFU/g IDS) }\end{array}$ & $\begin{array}{l}\text { Chitinase } \\
\text { yield } \\
(\mathrm{U} / \mathrm{g} \text { IDS })\end{array}$ & $\begin{array}{l}\beta \text {-Glucanase } \\
\text { yield (U/g }\end{array}$ & $\begin{array}{l}\text { Pectinase } \\
\text { IDield (U/g } \\
\text { IDS) }\end{array}$ \\
\hline None & 2.63 & 23.8 & 0.72 & 1.50 \\
Lees $(43 \%)$ & 6.16 & 46.4 & 2.69 & 1.82 \\
$\left(\mathrm{NH}_{4}\right)_{2} \mathrm{SO}_{4}(0.3 \%)$ & 5.15 & 25.8 & 2.11 & 5.06 \\
$\left(\mathrm{NH}_{4}\right)_{2} \mathrm{SO}_{4}(0.6 \%)$ & 5.72 & 30.5 & 2.87 & 6.91 \\
$\left(\mathrm{NH}_{4}\right)_{2} \mathrm{SO}_{4}(1.0 \%)$ & 4.64 & 37.8 & 2.90 & 7.95 \\
$\left(\mathrm{NH}_{4}\right)_{2} \mathrm{SO}_{4}(2.0 \%)$ & 3.13 & 23.6 & 2.08 & 9.70 \\
Urea $(0.2 \%)$ & 5.38 & 26.0 & 3.41 & 4.16 \\
Urea $(0.4 \%)$ & 5.51 & 34.2 & 6.14 & 7.52 \\
Urea $(0.6 \%)$ & 5.35 & 39.5 & 9.96 & 11.9 \\
Urea $(0.8 \%)$ & 5.11 & 44.6 & 15.5 & 19.7 \\
Urea $(1.2 \%)$ & 3.72 & 55.2 & 18.6 & 24.2 \\
Wheat bran $(2.0 \%)$ & 4.76 & 38.3 & 1.68 & 1.95 \\
Wheat bran $(4.0 \%)$ & 4.80 & 46.0 & 2.71 & 2.43 \\
Yeast extract $(1.0 \%)$ & 5.43 & 45.6 & 3.35 & 4.77 \\
Peptone $(1.0 \%)$ & 6.05 & 49.2 & 4.55 & 4.47 \\
Lees $(43 \%)$ & 6.65 & 47.8 & 8.32 & 9.83 \\
+ urea $(0.4 \%)$ & & & & \\
\hline
\end{tabular}

wastes can be suitable and substantially low cost substrates for fermentation.

Associated with the optimization of the culture conditions for increasing spore yield, the three extracellular enzymes chitinase, $\beta$-glucanase and pectinase were also investigated with respect to nitrogen sources. The chitinase and $\beta$-glucanase are fungal cell wall degrading enzymes, which are the key activities for anti-fungal pathogens (Markovich and Kononova, 2003). Pectinase is an elicitor for introducing plant disease resistance (Cervone et al., 1989). However, few studies have been reported in the literature on the contribution rates of these enzymes to inhibiting phytopathogens comparing with the spores, even though Nampoothiri et al. (2004) reported the antifungal chitinase production by Trichoderma harzianum. This study investigated the effect of nitrogen source on these enzymes yield preliminarily. It is noticeable that the chitinase yield (47.8 U/g IDS, enzyme action temperature $\left.40^{\circ} \mathrm{C}\right)$ in this study is much higher than those $(3.18 \mathrm{U} / \mathrm{g}$ dry substrate, enzyme action temperature $50^{\circ} \mathrm{C}$ ) reported in the literature (Nampoothiri et al., 2004). For further investigation of the enzymes production, evaluation of the effect of these enzymes on protecting plants from diseases by bioassay comparing with the spores is in process. The $\mathrm{pH}$ used in the methods for the enzymes assay is the optimum $\mathrm{pH}$ for the enzymes activity which was determined primarily.

Compost has been recognized and widely used as a conventional method for winery wastes treatment (Bertran et al., 2004). There are also some other methods for recovering several valuable materials from the wastes, such as tartrate recovery from grape skin and lees, and natural colours extraction from grape skin. However, residues (such as spent marc, waste effluents, etc.) from these processes are the key issues, which cause environmental problems. There is still a need for treatment of the waste residues. The utilization of the winery wastes reported in this study can also use spent marc as support substrate and the wine lees could supply the main nutrients for $T$. viride growth. This method can not only consume a wide variety of winery wastes, but also produce a high value-added and environmental friendly product-BCA.

\section{Conclusions}

A novel process for economical production of $T$. virde BCA was developed by solid state fermentation using grape marc and wine lees. T. viride WEBL0703 performed a high level of antagonistic activity toward the genera Cladosporium, Fusarium, Fulvia, Botrytis, Aspergillus, Penicillium, Mucor and Rhizopus. The maximum yields of $T$. viride conidia, chitinase, $\beta$-glucanase, and pectinase were up to $6.65 \times 10^{9} \mathrm{CFU} / \mathrm{g}$ IDS, $47.8 \mathrm{U} / \mathrm{g}$ IDS, $8.32 \mathrm{U} / \mathrm{g}$ IDS and $9.83 \mathrm{U} / \mathrm{g}$ IDS, respectively. This process is also an alternative method for winery wastes treatment.

\section{Acknowledgements}

This work was supported by the Australian Research Council International Linkage Fellowship (No. 
LX0560210) and the National Natural Science Foundation of China (No. 30600082). We thank Mr. Leon Deans and Orlando Wyndham Group Pty. Ltd., Adelaide, Australia for supplying grape marc and wine lees samples.

\section{References}

AOAC (Association of Official Analytical Chemists), 1995. Official methods of analysis. 16th ed. Washington DC.

APHA, 1998. Standard methods for the examination of water and wastewater. 20th ed. Washington DC: American Public Health Association/American Waster Works Association/Water Environment Federation.

Bai Z H, Zhang H X, Qi, H Y, Peng X W, Li B J, 2004. Pectinase production by Aspergillus niger using wastewater in solid state fermentation for eliciting plant disease resistance. Biores Technol, 95: 49-52.

Bailey D J, Gilligan C A, 1997. Biological control of pathozone behaviour and disease dynamics of Rhizoctonia solani by Trichoderma viride. New Phytol, 136: 359-367.

Bertran E, Sort X, Soliva M, Trillas I, 2004. Composting winery waste: Sludges and grape stalks. Biores Technol, 95: 203208.

Boby V U, Bagyaraj D J, 2003. Biological control of root-rot of Coleus forskohlii Briq. using microbial inoculants. World $J$ Microbiol Biotechnol, 19: 175-180.

Cervone F, Hahn M G, Lorenzo G D, Darvill A, Albersheim P, 1989. Host-pathogen interactions XXXIII. A plant protein converts a fungal pathogenesis factor into an elicitor of plant defense responses. Plant Physiol, 90: 542-548.

Chen X, Li Y, Du G, Chen J, 2005. Application of response surface methodology in medium optimization for spore production of Coniothyrium minitans in solid-state fermentation. World J Microbiol Biotechnol, 21: 593-599.

Chin-A-Woeng T F C, Bloemberg G V, Lugtenberg B J J, 2003. Phenazines and their role in biocontrol by Pseudomonas bacteria. New Phytologist, 157: 503-523.

Costa E, Teixidó N, Usall J, Atarés E, Viñas I, 2001. Production of the biocontrol agent Pantoea agglomerans strain CPA-2 using commercial products and by-products. Appl Microbiol Biotechnol, 56: 367-371.

Couto S R, Sanromán M A, 2006. Application of solid-state fermentation to food industry-A review. J Food Eng, 76: 291-302.

Dubois M, Gilles K A, Hamilton J K, Rebers P A, Smith F, 1956. Calorimetric method for determination of sugars and related substances. Anal Chem, 28: 350-356.

Ejechi B O, 2001. Wood biodeterioration control potential of Acalypha hispida leaf phenolic extract in combination with Trichoderma viride culture filtrate. World J Microbiol
Biotechnol, 17: 561-565.

Guo R, Liu X, Gao K, Gao B, Shi B, Zhen Z, 2002. Progress in biocontrol research with Trichoderma. Chinese J Biological Control, 18: 180-184.

Ji M, Li B, Chen J, Gu Z, Wang Y, 2005. Antifungal mechanisms of Trichoderma viride strain TR-8 against Fusarium oxysporum. Chinese J Biological Control, 21: 104-108.

Kolombet L V, Jigletsova S K, Derbyshev V V, Ezhov D V, Kosareva N I, Bystrova E V, 2001. Studies of mycofungicid, a preparation based on Trichoderma viride, for plant infection control. Appl Biochem Microbiol, 37: 98-102.

Kulminskaya A A, Tomsen K K, Shabalin K A, Sidorenko I A, Eneyskaya E V, Savel'ev A N, Neustroev K N, 2001. Isolation, enzymatic properties, and mode of action of an exo-1,3- $\beta$-glucanase from Trichoderma viride. Eur $J$ Biochem, 268: 6123-6131.

Limón M C, Chacón M R, Mejías R, Delgado-Jarana J, Rincón A M, Codón A C, Benítez T, 2004. Increased antifungal and chitinase specific activities of Trichoderma harzianum CECT 2413 by addition of a cellulose binding domain. Appl Microbiol Biotechnol, 64: 675-685.

Markovich N A, Kononova G L, 2003. Lytic enzymes of Trichoderma and their role in plant defense from fungal diseases: A review. Appl Biochem Microbiol, 39: 341-351.

Miller G L, 1959. Use of dinitrosalicylic acid for estimation of reducing sugar. Anal Chem, 31: 426-428.

Nampoothiri K M, Baiju T V, Sandhya C, Sabu A, Szakacs G, Pandey A, 2004. Process optimization for antifungal chitinase production by Trichoderma harzianum. Process Biochem, 39: 1583-1590.

Suresh P V, Chandrasekaran M, 1998. Utilization of prawn waste for chitinase production by the marine fungus Beauveria bassiana by solid state fermentation. World J Microbiol Biotechnol, 14: 655-660.

Verma M, Brar S K, Tyagi R D, Valéro J R, Surampalli R $\mathrm{Y}, 2005$. Wastewater sladge as a potential raw material for antagonistic fungus (Trichoderma sp.): Role of pretreatment and solids concentration. Water Research, 39: 3587-3596.

Vrije T, Antoine N, Buitelaar R M, Bruckner S, Dissevelt M, Durand A et al., 2001. The fungal biocontrol agent Coniothyrium minitans: Production by solid-state fermentation, application and marketing. Appl Microbiol Biotechnol, 56: 58-68.

Wang K C, Cha X F, Nan N L, Shen R Q, 2003. Trichoderma spp. for protecting plant from disease and its fermentation process. Chinese patent, publication No. CN 1422946A.

Zhao G, Lin F, Chen W, Tong X, Chen L, 1998. Biocontrol of seedling disease caused by Fusarium oxysporum f. sp. niveum with Trichoderma viride. Acta Agriculturae Zhejiangensis, 10: 206-209. 